\title{
Een investeringstoets voor vitale vennootschappen
}

\author{
Mr. E. Breukink*
}

\begin{abstract}
Deze bijdrage gaat over het onlangs verschenen WODCrapport 'Vitale vennootschappen in veilige handen'. Thans staat centraal de aanbeveling aan de wetgever om een publiekrechtelijk, sectorspecifiek instrumentarium te ontwikkelen waarmee ongewenst aandeelhouderschap in vitale vennootschappen kan worden tegengegaan.
\end{abstract}

\section{Inleiding}

In een eerder nummer van Maandblad voor Ondernemingsrecht stelde Van Slobbe zich vanuit een vennootschapsrechtelijk perspectief de vraag of het wenselijk is dat het verkrijgen van zeggenschap in bepaalde vennootschappen wordt getoetst op mogelijke bedreigingen voor het algemeen belang. ${ }^{1}$ Deze vraag beantwoordt hij bevestigend. Als reden noemt Van Slobbe dat er vennootschappen bestaan waar de Nederlandse samenleving een algemeen belang bij heeft, terwijl dat belang in het vennootschapsrecht een zeer geringe rol speelt. Vennootschappen die voor Nederland 'vitaal' zijn, of dat in de loop der tijd worden, ontlenen volgens Van Slobbe onvoldoende bescherming aan het vennootschapsrecht. Ik deel die conclusie. ${ }^{2}$ Wel merk ik alvast op dat een vennootschap van algemeen belang niet altijd, of beter gezegd: vaak niet, een vitale vennootschap is. Paragraaf 2 biedt verduidelijking.

In deze bijdrage meng ik mij niet in de discussie of het algemeen belang, maatschappelijk belang, nationaal belang of een belang van soortgelijke strekking een belang is waar bestuurders en commissarissen van bepaalde vennootschappen zich bij de vervulling van hun taak mede naar moeten richten. ${ }^{3}$ Evenmin ga ik in op de vraag of een beschermingsstichting

* Mr. E. Breukink is als promovendus verbonden aan het Van der Heijden Instituut, onderdeel van het Onderzoekcentrum Onderneming \& Recht (OO\&R), van de Radboud Universiteit Nijmegen. Hij bereidt een proefschrift voor over de agenda en het agenderingsrecht bij kapitaalvennootschappen.

1. P.W.M. van Slobbe, Overnamegevechten, ongewenste investeerders en vitale vennootschappen. Is een investeringstoets ter waarborging van 'het algemeen belang' wenselijk?, MvO 2016, afl. 7, p. 169-179.

2. Met de kanttekening dat sommige vitale vennootschappen mijns inziens al wel voldoende bescherming ontlenen aan sectorale wetgeving. Zie bijv. art. 86 f Elektriciteitswet 1998 jo. art. $26 \mathrm{Mw}$.

3. Zie voor een beeld van deze discussie de bijdragen in het themanummer van het WPNR 'Overname en algemeen belang', WPNR 2015/7048. (van een dergelijke vennootschap) de calloptie mag inroepen op grond van genoemde belangen. ${ }^{4}$

Ik richt mij in deze bijdrage op een aanbeveling uit het WODC-rapport 'Vitale vennootschappen in veilige handen' (hierna: het WODC-rapport). ${ }^{5}$ Het gaat om de aanbeveling aan de wetgever om een publiekrechtelijk, sectorspecifiek instrumentarium te ontwikkelen waarmee ongewenst aandeelhouderschap in vitale vennootschappen kan worden tegengegaan. ${ }^{6}$ Ik schets hoe de kern van het instrumentarium eruit kan zien (par. 3). Vervolgens toets ik in hoeverre de consultatieversie van het wetsvoorstel Wet voorkoming ongewenste zeggenschap telecommunicatie ${ }^{7}$ in lijn is met de aanbeveling uit het WODC-rapport (par. 4 en 5). Alvorens daaraan toe te komen, definieer ik de vitale vennootschap (par. 2).

\section{De vitale vennootschap}

Een vitale vennootschap is gerelateerd aan de nationale veiligheid. De nationale veiligheid moet worden onderscheiden van de begrippen maatschappelijk belang en algemeen of publiek belang (hierna aangeduid met de enkele term 'publiek belang'). Men spreekt van een maatschappelijk belang als de behartiging ervan voor de samenleving als geheel gewenst is. Een maatschappelijk belang wordt een publiek belang op het moment dat de overheid zich de behartiging van het belang

4. Zie voor mijn standpunt hieromtrent C.D.J. Bulten e.a., Vitale vennootschappen in veilige handen, Nijmegen/Den Haag: OO\&R, Radboud Universiteit Nijmegen/WODC 2017, p. 62-63.

5. Het WODC-rapport 'Vitale vennootschappen in veilige handen' is uitgebracht door het Onderzoekcentrum Onderneming \& Recht (OO\&R) van de Radboud Universiteit Nijmegen. De auteur makte deel uit van het onderzoeksteam, dat onder leiding stond van C.D.J. Bulten en B.J. de Jong. Het rapport behelst de resultaten van een onderzoek naar de wijze waarop (buitenlands) aandeelhouderschap gevolgen kan hebben voor de nationale veiligheid.

6. Bulten e.a. 2017, p. 248-258 en ix

7. Wijziging van de Telecommunicatiewet ter voorkoming van ongewenste zeggenschap over elektronische communicatienetwerken en -diensten waarvan misbruik of uitval de nationale veiligheid of openbare orde kan bedreigen (Wet voorkoming ongewenste zeggenschap telecommunicatie). 
aantrekt. ${ }^{8}$ Voor de behartiging van veel maatschappelijke belangen is bemoeienis van de overheid echter niet vereist. ${ }^{9}$

De nationale veiligheid is een voorbeeld van een maatschappelijk belang dat de overheid zich wel heeft aangetrokken. Daarmee is de nationale veiligheid dus ook een publiek belang.

De door het kabinet geïntroduceerde Strategie Nationale Veiligheid concretiseert het begrip 'nationale veiligheid' door aan te geven wanneer zij in het geding is. Dat is zo als:

'vitale belangen van de Nederlandse staat en/of samenleving zodanig bedreigd worden dat sprake is van - potentiële - maatschappelijke ontwrichting. ${ }^{10}$

De nationale veiligheid betreft dus vitale belangen van de Nederlandse Staat of samenleving. Het kabinet identificeert er vijf. ${ }^{11}$ Binnen de context van vennootschappen en de investeringen daarin speelt met name - maar niet uitsluitend - het vitale belang 'economische veiligheid'. ${ }^{12}$

Sinds 2004 zijn de sectoren in kaart gebracht die invloed hebben op de vitale belangen en dus op de nationale veiligheid. Deze sectoren zijn de vitale sectoren. Aanvankelijk vormden de vitale sectoren gezamenlijk de 'vitale infrastructuur' van Nederland. Inmiddels is echter de focus verlegd naar bepaalde processen binnen de vitale sectoren. Deze processen - ook aangeduid als vitaal - vormen nu de vitale infrastructuur. ${ }^{13}$

In een vitaal proces zijn verschillende partijen actief. Als een van die partijen de rechtsvorm NV of BV heeft, is zij mogelijk een vitale vennootschap. ${ }^{14}$ Het moet dan wel gaan om een NV of BV die van wezenlijk belang is voor de continuïteit en de weerbaarheid van het vitale proces. Door aan te knopen bij de continuïteit en de weerbaarheid van het vitale proces worden NV's en BV's uitgesloten die (met hun werkzaamheden) wel actief zijn in een vitaal proces, maar daarmee niet aan één of meer van de door de Werkgroep Economische Veiligheid onderscheiden generieke categorieën van veiligheidsbelangen

8. WRR, Het borgen van publiek belang, Den Haag: Sdu Uitgevers 2000, p. 19-21. Te raadplegen via: www.wrr.nl/publicaties/rapporten/2000/04/ 26/het-borgen-van-publiek-belang. Zie ook J. Nijland, De overheidsonderneming. Overheidsinvloed in kapitaalvennootschappen nader beschouwd (diss. Leiden; Ars Notariatus, deel 154), Kluwer: Deventer 2013, p. 17-21.

9. Een voorbeeld van een maatschappelijk belang is het aanbod van voldoende voedingsmiddelen.

10. Nationaal Coördinator Terrorismebestrijding en Veiligheid, Strategie Nationale Veiligheid, 2007, p. 4. Te raadplegen via: www.nctv.nl/ binaries/strategie-nationale-veiligheid-2007_tcm31-32502.pdf.

11. Te weten: territoriale veiligheid, economische veiligheid, ecologische veiligheid, fysieke veiligheid en sociale en politieke stabiliteit (Nationaal Coördinator Terrorismebestrijding en Veiligheid, Nationaal Veiligheidsprofiel, 2016, p. 21-22, te raadplegen via: www.nctv.nl/binaries/ Nationaal\%20Veiligheidsprofiel\%202016_tcm31-232083.pdf).

12. Zie hierover verder Bulten e.a. 2017, p. 19.

13. Zie voor voorbeelden van vitale processen Bulten e.a. 2017, p. 18.

14. Waarmee ik niet zeg dat een vennootschap naar buitenlands recht voor Nederland niet vitaal kan zijn. Waar ik verder spreek over vitale vennootschappen, doel ik echter uitsluitend op vitale NV's en BV's. raken. ${ }^{15}$ Bij die veiligheidsbelangen gaat het om de vraag of het aandeelhouderschap in de desbetreffende vennootschap een gevaar kan opleveren voor:

1. de continuïteit van de vitale sector of het vitale proces;

2. de integriteit en exclusiviteit van belangrijke informatie (zoals specialistische technologische kennis, staatsgeheimen, persoonsgegevens en politiek-strategische informatie);

3. het functioneren van de democratische rechtsorde in Nederland. ${ }^{16}$

Om te beoordelen of een concrete NV of BV van wezenlijk belang is voor de continuïteit en/of weerbaarheid van een vitaal proces is een vorm van feitelijke toetsing vereist. De aspecten die daarbij een rol kunnen spelen, zijn bijvoorbeeld de marktpositie van de vennootschap en de grootte van de onderneming. Een voorbeeld van een vitale vennootschap is TenneT TSO BV (thans via TenneT Holding BV een 100\%staatsdeelneming). TenneT TSO BV beheert het Nederlandse hoogspanningsnet.

Van alle vennootschappen die in Nederland actief zijn, zal slechts een klein percentage als vitaal kwalificeren. ${ }^{17}$ Het is verder goed om in het achterhoofd te houden dat een nietvitale vennootschap in de loop der tijd vitaal kan worden, en vice versa.

\section{De aanbeveling}

De aanbeveling die hier centraal staat, is de aanbeveling uit het WODC-rapport aan de wetgever om een publiekrechtelijk, sectorspecifiek instrumentarium te ontwikkelen waarmee ongewenst aandeelhouderschap in vitale vennootschappen kan worden tegengegaan. Ik loop de verschillende elementen die deze aanbeveling bevat op hoofdlijnen langs.

\subsection{Publiekrechtelijk}

Zoals gezegd heeft de overheid zich de nationale veiligheid als publiek belang aangetrokken. Daarbij past een publiekrechtelijk instrumentarium. Het gegeven dat een bepaald belang een publiek belang is, maakt reeds dat de behartiging daarvan niet (uitsluitend) aan private partijen mag worden overgelaten. Bovendien hebben de gangbare alternatieven - het voeren van een staatsdeelnemingenbeleid en de toegestane privaatrechtelijke beschermingsconstructies - belangrijke nadelen. Het aanhouden van staatsdeelnemingen is bijvoorbeeld een (bijzon-

15. Ik merk op dat een vennootschap die (met haar werkzaamheden) aan een sectorspecifiek veiligheidsbelang raakt ook vitaal kan zijn. Deze sectorspecifieke veiligheidsbelangen (zoals bijv. de veiligheid en non-proliferatie van chemische en nucleaire wapens in de nucleaire sector) laat ik verder buiten beschouwing. Zie hierover Bulten e.a. 2017, p. 22.

16. Werkgroep Economische Veiligheid, Tussen naïviteit en paranoia, 2014, p. 17. Te raadplegen via: www.rijksoverheid.nl/documenten/rapporten/ 2014/06/11/tussen-naiviteit-en-paranoia.

17. Men kan erover discussiëren of het begrip 'vitale vennootschap' opgerekt zou moeten worden, zodat bijv. ook (meer) vennootschappen uit de topsectoren eronder vallen. 
der) kostbare aangelegenheid. ${ }^{18}$ Een stichting preferente aandelen - de onder Nederlandse beursvennootschappen meest voorkomende beschermingsconstructie ${ }^{19}$ - biedt slechts tijdelijke bescherming. ${ }^{20}$ Daarnaast is het niet duidelijk of het stichtingsbestuur bij het nemen van het besluit om de calloptie in te roepen (altijd) de nationale veiligheid mag betrekken. Als dat al het geval is, staat het vervolgens ter beoordeling van het bestuur van de stichting of er sprake is van een gevaar voor de nationale veiligheid. De bescherming van een publiek belang komt zo in handen van een private partij. Ik acht dat onwenselijk.

\subsection{Sectorspecifiek}

Het voorgestelde instrumentarium dient sectorspecifiek te zijn. $^{21}$ Idealiter moet de verschillende sectorspecifieke wetgeving vervolgens wel een (zo veel mogelijk) coherent geheel vormen. Er zijn verschillende redenen te noemen waarom sectorspecifieke wetgeving de voorkeur heeft boven een generieke wet. De belangrijkste reden is mijns inziens dat een sectorspecifieke wet eerder 'Europaproof zal zijn dan een generieke. Dit in verband met de noodzakelijke proportionaliteit van maatregelen die de marktwerking kunnen beïnvloeden. ${ }^{22}$ Een andere reden is dat sectorspecifieke wetgeving maatwerk, en daarmee betere bescherming kan bieden. ${ }^{23}$ De ernst van het gevaar voor de nationale veiligheid verschilt immers per sector. Men kan zich voorstellen dat de gevaren van uitval in de nucleaire sector van een andere orde zijn dan de gevaren in bijvoorbeeld de transportsector. ${ }^{24}$

\subsection{Instrumentarium ${ }^{25}$}

Een effectief instrumentarium kent in ieder geval een meldingsplicht voor voorgenomen wijzigingen van zeggenschap in vitale vennootschappen. Hoe een 'wijziging van zeggenschap' naar mijn mening zou moeten worden gedefinieerd, licht ik toe in paragraaf 3.4. Alleen door middel van ex-antetoetsing is het mogelijk om schade aan de onderscheiden veiligheidsbelangen te voorkomen. Bij toetsing ex post kan immers al schade zijn toegebracht aan bijvoorbeeld de continuïteit van het vitale proces in kwestie. Het meest effectief lijkt mij een rege-

18. Zie Jaarverslag Beheer Staatsdeelnemingen 2015, p. 8. Ik wil overigens zeker niet alle daar genoemde vennootschappen op voorhand als vitaal kwalificeren.

19. Van de 71 beursfondsen hebben er 32 een stichting preferente aandelen, zie P. Kakebeeke \& E. Engel, De toverdoos van beschermingsconstructies, Het Financieele Dagblad 12 april 2017.

20. HR 18 april 2003, ECLI:NL:HR:2003:AF2161, JOR 2003/110 (RNA), r.o. 3.7.

21. Anders: J. Nijland \& C. de Groot, Nationale publieke belangen in de telecomsector afdoende beschermd tegen ongewenste zeggenschap? O\&F 2017, afl. 2, p. 40. Zij pleiten voor een sectoroverschrijdend instrumentarium.

22. Zie in dit verband HvJ EG 14 maart 2000, C-54/99, ECLI:NL:XX: 2000:AC3501 (Église de scientologie), r.o. 21-23, HvJ EG 13 mei 2003, C-463/00, ECLI:EU:C:2003:273 (Commissie/Spanje), r.o. 74-79 en Kamerstukken II 2009/10, 31350, 8, p. 2.

23. Zie hierover verder Bulten e.a. 2017, p. 249.

24. Zie ook de MvT bij de consultatieversie van het wetsvoorstel Wet voorkoming ongewenste zeggenschap telecommunicatie, p. 8.

25. Art. 86 f Elektriciteitswet 1998 en art. 66e Gaswet kennen vrijwel exact het systeem van ex-antetoetsing zoals ik dat in deze paragraaf beschrijf. ling waarbij zowel de vitale vennootschap als de koper en de verkoper van de aandelen verplicht zijn om een voorgenomen wijziging van zeggenschap in de vennootschap te melden. Een melding van een van de betrokken partijen ontslaat de andere partijen van hun meldingsplicht. Op basis van de informatie die bij de melding is verstrekt ${ }^{26}$ en aanvullend eigen onderzoek van de toetsende overheidsinstantie kan de instantie vervolgens besluiten de wijziging van zeggenschap te verbieden, daar voorwaarden aan te verbinden of deze toe te staan. In het laatste en voorlaatste geval krijgt de investeerder (eventueel onder voorwaarden) een benodigde verklaring van geen bezwaar (vvgb). De toetsende overheidsinstantie kan bijvoorbeeld de minister van Economische Zaken zijn ${ }^{27}$ of een gemengde commissie van overheidsvertegenwoordigers. Mijn voorkeur gaat uit naar het laatste. Een gemengde commissie kan een (deels) wisselende samenstelling hebben. Experts (op het gebied van veiligheid) binnen de sector waarin geïnvesteerd wordt, nemen dan zitting. ${ }^{28}$

Wanneer de zeggenschap wijzigt zonder dat de meldingsplicht in acht is genomen, zou dit tot nietigheid van de daaraan ten grondslag liggende rechtshandeling moeten leiden. Hetzelfde geldt voor de rechtshandeling die leidt tot wijziging van zeggenschap terwijl de toetsende overheidsinstantie die wijziging verbood. ${ }^{29}$ Een uitzondering is denkbaar wanneer de vitale vennootschap beursgenoteerd is. Nietigheid van rechtshandelingen op de effectenmarkten kan het functioneren van deze markten namelijk in gevaar brengen. ${ }^{30}$ Wel wijs ik erop dat desondanks ook de Wet op het financieel toezicht (Wft) de mogelijkheid kent dat sommige rechtshandelingen nietig of vernietigbaar zijn. ${ }^{31} \mathrm{Bij}$ de invoering van artikel 1:6p (thans art. 1:23) Wft werd in dat verband door het Tilburg Law and Economics Center (TILEC) geopperd om de aankoop van aandelen zonder vvgb als bedoeld in artikel 3:95 Wft aantastbaar te laten zijn. ${ }^{32}$ Voor die optie is destijds niet gekozen. Binnen de context van een effectieve investeringstoets ten behoeve van de nationale veiligheid is nader onderzoek op dit punt geboden, lijkt mij.

26. Welke informatie dat is, hangt samen met de criteria waarop aandeelhouders worden getoetst (Bulten e.a. 2017, p. 255). Zie voor een voorbeeld de bijlage bij art. 2 van de Regeling melding wijziging zeggenschap Elektriciteitswet 1998 en Gaswet.

27. Hetgeen in bijv. Duitsland bij de sektorübergreifende Prüfung het geval is (\$55-59 Außenwirtschaftsverordnung).

28. Zie in dit verband ook het advies van de OESO, Guidelines for recipient country investment policies relating to national security, 2009, p. 3. Te raadplegen via: www.oecd.org/investment/investment-policy/43384486. pdf.

29. Art. 3:40 lid $1 \mathrm{BW}$.

30. Kamerstukken II 2005/06, 29708, 19, p. 392.

31. Art. 1:23 Wft. Zie over de verhouding van dit artikel tot art. 3:40 BW verder Asser/Wansink, Van Tiggele \& Salomons 7-IX*2012/91.

32. Kamerstukken II 2005/06, 29708, 19, p. 393. Zie voor de position paper van TILEC W.H. van Boom \& R.H.J. van Bijnen, Nietigheid bij overtreding van financiële toezichtwetgeving (Position Paper TILEC Universiteit van Tilburg, in opdracht van het Ministerie van Financiën), Tilburg: TILEC 2005. 


\section{Maandblad \\ Ondernemingsrecht}

Een onwelgevallig besluit van de toetsende overheidsinstantie zal aan de rechter moeten kunnen worden voorgelegd. Dit omdat wanneer de instantie besluit om een transactie te verbieden, hiermee mogelijk een inbreuk wordt gemaakt op het ongestoorde genot van eigendom van de verkopende partij. ${ }^{33}$ Om die inbreuk te kunnen rechtvaardigen vereist het Europees Hof voor de Rechten van de Mens onder meer dat tegen een dergelijk besluit een met voldoende waarborgen omklede rechtsgang openstaat. ${ }^{34}$

Voor aanvullende suggesties om het instrumentarium te complementeren verwijs ik naar het WODC-rapport. ${ }^{35}$

\subsection{Ongewenst aandeelhouderschap}

Het is van belang dat partijen weten wanneer mogelijk sprake is van ongewenst aandeelhouderschap in een vitale vennootschap. Met andere woorden: het toepassingsbereik van de regeling moet duidelijk zijn. Als het dat niet is, dreigt strijdigheid met de Europeesrechtelijke bepalingen over vrij verkeer van kapitaal (art. 63-66 van het Verdrag betreffende de werking van de Europese Unie (VWEU)) en vrij verkeer van vestiging (art. 49-55 VWEU). Een nationale regel mag die vrijheden beperken, mits aan een aantal voorwaarden is voldaan. Een regeling met een vaag toepassingsbereik dreigt in strijd te komen met de proportionaliteitseis. ${ }^{36}$

Om het toepassingsbereik te kunnen bepalen moet de sectorspecifieke wetgeving ophelderen:

1. voor welke vennootschappen de wetgeving geldt;

2. welke investeerders ongewenst zijn; en

3. op welke investeringen de toets van toepassing is. ${ }^{37}$

Ik maak ten aanzien van deze drie punten een enkele opmerking.

Met betrekking tot (1) heeft het mijn voorkeur om ter verduidelijking van welke vennootschappen vitaal zijn in de wet de vitale processen binnen de sector te benoemen. Elke NV of BV die direct of indirect betrokken is bij een van de vitale processen valt dan onder het toepassingsbereik van de regeling. Op het moment dat een investering in een van die NV's of BV's wordt getoetst, wordt aan de hand van concrete criteria bepaald of de vennootschap in kwestie ook daadwerkelijk

33. Zie art. 1 van het Eerste Protocol bij het Verdrag tot bescherming van de rechten van de mens en de fundamentele vrijheden (EP). Aandelen en de aan aandelen verbonden rechten (dus ook het recht op verkoop) vallen onder het eigendomsbegrip (EHRM 23 september 1982, 7151/75 en 7152/75, ECLI:NL:XX:1982:AC7724, NJ 1989/290 m.nt. Alkema (Sporrong \& Lönnroth/Zweden), r.o. 69.

34. EHRM 29 maart 2011, 33949/05, ECLI:NL:XX:2011:BR0433, EHRC 2011/99 (Potomska \& Potomski/Polen), \$74 en EHRM 26 september 2006, 33949/05, ECLI:NL:XX:2011:BR0433, EHRC 2006/138 (Fleri Soler \& Camilleri/Malta), r.o. 79. Zie hierover verder Bulten e.a. 2017, p. 158-159.

35. Bulten e.a. 2017 , p. $256-257$.

36. HvJ EU 10 november 2011, C-212/09, ECLI:EU:C:2011:717 (Commissie/Portugal), r.o. 85 en 87.

37. Bulten e.a. 2017, p. 251-254. vitaal is. Naar mijn mening biedt dit systeem voldoende rechtszekerheid voor potentiële investeerders. Voorwaarde is wel dat de vitale processen duidelijk zijn gedefinieerd en afgebakend. ${ }^{38}$

Of een investeerder ongewenst is (2), hangt met name af van zijn motieven. Het valt niet uitsluitend op basis van nationaliteit of herkomst te zeggen of een investeerder oneigenlijke, niet-economische motieven met zijn investering dient. Het maken van een onderscheid tussen binnenlandse of Europese investeerders enerzijds en buitenlandse of niet-Europese investeerders anderzijds is daarom weinig zinvol. Nationaliteit of herkomst kan echter wel een indicatie zijn bij de beoordeling of een investeerder al of niet wenselijk is. Een andere indicator is bijvoorbeeld de ondoorzichtigheid van de eigendomsstructuur van de investeerder (wie is de uiteindelijk belanghebbende?). Een absoluut investeringsverbod kan gelden voor investeerders die op een sanctielijst staan. Het ligt voor de hand om aan te sluiten bij de beschikbare lijst die door de Europese Unie is opgesteld. ${ }^{39}$

Dan de vraag op welke investeringen de toets van toepassing dient te zijn (3). Om ongewenste investeringen zo veel mogelijk te ondervangen lijkt het mij onvoldoende om slechts investeringen te toetsen die aan een getalsmatig criterium voldoen. In plaats daarvan kan aansluiting worden gezocht bij artikel 26 van de Mededingingswet (Mw). Aandeelhouderschap dat leidt tot de mogelijkheid om beslissende invloed uit te oefenen op de ondernemingsactiviteiten van de vennootschap valt dan onder het toepassingsbereik van de regeling. Zowel juridische als feitelijke omstandigheden zijn relevant bij de beoordeling of sprake kan zijn van beslissende invloed. Om houvast te bieden kan als ondergrens een aandelenbelang van $10 \%$ als richtsnoer dienen. ${ }^{40}$ Onder welke feitelijke omstandigheden bij een lager percentage een beslissende invloed kan worden aangenomen, is deels sectorafhankelijk. Een voorbeeld van een feitelijke, niet-sectorafhankelijke omstandigheid is acting in concert.

Een bijkomend voordeel van aansluiting bij artikel $26 \mathrm{Mw}$ is dat ook wijzigingen van zeggenschap die geen verband houden met een transactie van aandelen onder het toepassingsbereik komen te vallen. Zo kan bijvoorbeeld een meldingsplicht komen te rusten op de kredietverstrekker die in ruil voor het krediet een contractueel zeggenschapsrecht krijgt waarmee hij hervormingen in de bedrijfsvoering kan afdwingen.

Voorts leidt aansluiting bij artikel $26 \mathrm{Mw}$ ook tot coherentie tussen de sectorspecifieke wetgeving. Artikel $86 f$ Elektriciteits-

38. Het alternatief van het in de wet verwijzen naar een bij AMvB aangewezen en uit te breiden lijst met vitale vennootschappen lijkt mij in ieder geval niet meer rechtszekerheid te brengen (zie voor een voorbeeld van dit systeem art. 5 van de Wet gegevensverwerking en meldplicht cybersecurity).

39. Zie voor deze lijst eeas.europa.eu/headquarters/headquarters-homepage_ en/8442/Consolidated\%20list\%20of\%20sanctions.

40. Vgl. art. 3:95 jo. art. 1:1 Wft. Zie hierover verder: Bulten e.a. 2017, p. 254. 
wet 1998 en artikel 66e Gaswet verwijzen voor de uitleg van het begrip 'zeggenschap' al naar dit artikel. Deze bepalingen geven de minister van Economische Zaken de bevoegdheid om een wijziging van zeggenschap in (de beheerder van) respectievelijk een grote elektriciteitsproductie-installatie en een LNGinstallatie te toetsen aan onder meer de openbare veiligheid.

Om het systeem voor wat betreft de duidelijkheid over het toepassingsbereik volledig te maken, kan voor potentiële investeerders de mogelijkheid worden gecreëerd om - naar Duits voorbeeld - te verzoeken om een soort Unbedenklichkeitsbescheinigung. ${ }^{41}$ Op verzoek van de potentiële investeerder verklaart de toetsende overheidsinstantie dan of de voorgenomen investering al of niet onder het toepassingsbereik van de regeling valt. Als dat niet het geval is, kan de transactie zonder melding doorgang vinden. Blijkt de regeling wél op de investering van toepassing te zijn, dan kan de overheidsinstantie in haar reactie om de aanvullende informatie verzoeken die nodig is om aan de meldingsplicht te voldoen. Wordt dat laatste verzoek door de investeerder ingewilligd, dan is hiermee de melding compleet.

\section{De consultatieversie}

Op 16 februari 2017 verscheen de consultatieversie van het wetsvoorstel Wet voorkoming ongewenste zeggenschap telecommunicatie (hierna: consultatieversie). Het doel van de voorgestelde regeling is de nationale veiligheidsbelangen te beschermen voor zover die belangen geschaad kunnen worden door de uitoefening van zeggenschap in partijen binnen de telecommunicatiesector. Onder het toepassingsbereik van de consultatieversie vallen niet slechts kapitaalvennootschappen. ${ }^{42}$

Het is de vraag in hoeverre de aanbeveling uit het WODCrapport en de consultatieversie met elkaar overeenstemmen. In deze paragraaf bespreek ik het instrumentarium waarin de consultatieversie voorziet. Ik doe dat aan de hand van de elementen die de aanbeveling uit het WODC-rapport bevat. In paragraaf 5 toets ik in hoeverre de consultatieversie aan de aanbeveling uit het WODC-rapport voldoet.

\subsection{Publiekrechtelijk en sectorspecifiek}

De consultatieversie voorziet in een publiekrechtelijk instrumentarium ter voorkoming van ongewenste zeggenschap in specifiek de telecommunicatiesector. ${ }^{43} \mathrm{Er}$ worden bij wet bevoegdheden voor de minister van Economische Zaken (hierna: de minister) gecreëerd, waarmee hij ongewenste zeggenschap in de telecommunicatiesector dient tegen te gaan.

\subsection{Het 'houd-of verkrijgverbod'}

De kern van het voorgestelde instrumentarium is de bevoegdheid van de minister om het houden of verkrijgen van overwegende zeggenschap in een telecommunicatiepartij onder

41. Vgl. $\$ 58$ lid 1 Außenwirtschaftsverordnung.

42. Zie art. 14 a. 2 lid 3 jo. art. 14 a. 1 consultatieversie.

43. Art. 14 a. 2 e.v. consultatieversie. omstandigheden te verbieden. ${ }^{44}$ Degene aan wie een verbod is opgelegd, dient binnen een redelijke termijn de zeggenschap te beëindigen of terug te brengen, zodat niet langer sprake is van overwegende zeggenschap. ${ }^{45}$ In paragraaf 4.3 bespreek ik wat de consultatieversie onder 'overwegende zeggenschap' verstaat.

De rechtsgevolgen van het handelen in strijd met een 'houdof verkrijgverbod' zijn uiteenlopend. De verkrijging van aandelen in strijd met een 'verkrijgverbod' is nietig, ${ }^{46}$ tenzij het gaat om de verkrijging van aan de beurs verhandelde aandelen. In dat geval is de verkrijging rechtsgeldig, met dien verstande dat de verkrijger de aan de verkregen aandelen verbonden zeggenschapsrechten niet zal kunnen uitoefenen. De minister verbiedt dat en de vennootschap geeft gevolg aan het verbod. ${ }^{47}$ Dat doet zij door bijvoorbeeld degene aan wie het verbod is opgelegd voorafgaand aan de aandeelhoudersvergadering niet als stemgerechtigde te registreren en hem zo nodig de toegang tot de vergadering te weigeren. ${ }^{48}$ Alle eventuele schakels tussen de vennootschap en de aandeelhouder moeten meewerken aan het verbod. ${ }^{49} \mathrm{Om}$ te verzekeren dat het verbod effect sorteert, kan de minister bovendien een bewindvoerder benoemen die hierop toeziet. De vennootschap moet de opdrachten van de bewindvoerder opvolgen. ${ }^{50}$

De achterliggende gedachte van het systeem van het 'verkrijgverbod' is dat de aantastbaarheid van rechtshandelingen op de effectenmarkten het functioneren van deze markten in gevaar kan brengen. ${ }^{51}$ In paragraaf 3.3 makte ik over dit punt al enkele opmerkingen.

Overtreding van een 'houdverbod' heeft dezelfde gevolgen als overtreding van een verkrijgverbod dat geldt ten aanzien van aan de beurs verhandelde aandelen.

Samengevat: in alle gevallen leidt overtreding van een houd- of verkrijgverbod tot schorsing van de zeggenschapsrechten, tenzij het gaat om de verkrijging van aandelen die niet aan de beurs verhandeld worden, dan is de verkrijging nietig.

Een verbod op het houden of verkrijgen van overwegende zeggenschap is een voor bezwaar en beroep vatbaar besluit als bedoeld in artikel 1:3 van de Algemene wet bestuursrecht (Awb). ${ }^{52}$

44. Art. 14 a. 2 consultatieversie.

45. Art. $14 a .10$ lid 1 consultatieversie.

46. Dat wil zeggen dat de gehele transactie nietig is. Niet slechts dat gedeelte van de transactie dat leidt tot overschrijding van de grens voor overwegende zeggenschap (MvT bij de consultatieversie, p. 6).

47. Art. $14 a .7$ lid 1 en $14 a .8$ consultatieversie.

48. MvT bij de consultatieversie, p. 23.

49. Art. 14 a. 8 consultatieversie.

50. Art. 14 a.9 lid 1 consultatieversie.

51. MvT bij de consultatieversie, p. 6.

52. MvT bij de consultatieversie, p. 9. 


\section{Maandblad \\ Ondernemingsrecht}

\subsection{Het toepassingsbereik}

Ten aanzien van het toepassingsbereik van de consultatieversie kan een onderscheid worden gemaakt op welke vennootschappen zij ziet en voor welke investeringen zij geldt.

\section{Welke vennootschappen?}

De consultatieversie bepaalt welke vennootschappen onder het toepassingsbereik van de regeling vallen. Artikel 14a.2 lid 3 sluit daartoe aan bij enkele (sub)processen in de telecommunicatiesector. ${ }^{53}$ Een vennootschap die als aanbieder of anderszins, direct of indirect, feitelijke macht over een subproces in de telecommunicatiesector kan uitoefenen, valt onder de regeling. Een dergelijke partij wordt aangeduid als een telecommunicatiepartij. Voorbeelden van subprocessen zijn hostingdiensten, internetknooppunten en datacenters. De in het artikel genoemde processen kunnen bij algemene maatregel van bestuur $(\mathrm{AMvB})$ worden aangevuld.

\section{Welke investeringen?}

Het aandeelhouderschap in een NV of BV die kwalificeert als telecommunicatiepartij is volgens de consultatieversie onwenselijk wanneer het overwegende zeggenschap in de vennootschap met zich brengt en deze zeggenschap tot relevante invloed in de telecommunicatiesector leidt, waardoor de nationale veiligheid of openbare orde in gevaar kan komen. ${ }^{54}$ Hieronder zal ik de verschillende elementen van deze bepaling nader behandelen.

\section{- Overwegende zeggenschap}

Van overwegende zeggenschap is sprake indien de houder of verkrijger:

'a. alleen of tezamen met personen met wie in onderling overleg wordt gehandeld, rechtstreeks of middellijk over ten minste 30 procent van de stemmen in de algemene vergadering beschikt;

b. al dan niet krachtens overeenkomst met anderen, alleen of samen met personen met wie in onderling overleg wordt gehandeld, meer dan de helft van de bestuurders of van de commissarissen kan benoemen of ontslaan, ook indien alle stemgerechtigden stemmen;

c. beschikt over een of meer aandelen met een bijzonder statutair recht inzake de zeggenschap; (...)'.55

\section{- Relevante invloed}

Volgens de consultatieversie is er sprake van relevante invloed in de telecommunicatiesector indien misbruik of opzettelijke uitval van de telecommunicatiepartij (en eventuele andere telecommunicatiepartijen waarin overwegende zeggenschap wordt gehouden of verkregen) kan leiden tot één of meer van

\footnotetext{
53. Er is vanwege o.a. de snelle ontwikkelingen in de telecommunicatiesector bewust niet voor gekozen om de vitale vennootschappen vooraf aan te wijzen (MvT bij de consultatieversie, p. 7).

54. Art. 14 a. 2 lid 1 consultatieversie.

55. Art. 14 a. 3 consultatieversie.
}

de in artikel 14a.2 genoemde (gedetailleerde) gevolgen. Een voorbeeld is wanneer het opzettelijk staken van de werkzaamheden van de NV of BV kan leiden tot een langdurige onderbreking van de beschikbaarheid of verificatie van een aanzienlijk deel van de diensten en toepassingen die worden geleverd via het internet. ${ }^{56} \mathrm{Bij} \mathrm{AMvB}$ kunnen de gevolgen worden aangevuld. ${ }^{57}$

- Gevaar voor de nationale veiligheid of openbare orde In de consultatieversie is in artikel $14 a .4$ een lijst met omstandigheden opgenomen aan de hand waarvan de minister kan bepalen of door het houden of verkrijgen van de overwegende zeggenschap de nationale veiligheid of openbare orde in gevaar kan komen. Deze omstandigheden zien op de investeerder. Een voorbeeld van een omstandigheid die de consultatieversie noemt, is het door de houder of beoogd verkrijger onderhouden van nauwe banden met een 'ongewenst persoon' (sub d). Door wie die persoon ongewenst moet zijn, wordt echter niet duidelijk. De overige omstandigheden die de consultatieversie noemt, bevatten eveneens een aantal onbepaalde termen. $Z_{0}$ is het bijvoorbeeld niet helder wanneer de houder of beoogd verkrijger 'geen goede staat van dienst' heeft inzake beveiliging van communicatie dan wel de continuïteit van dienstverlening hiervan (sub c). Ook is niet nader bepaald wanneer de veiligheidssituatie in het land van vestiging van de houder of de beoogd verkrijger, of van de landen van de omliggende regio, 'onzeker of slecht' is (sub e). De lijst met omstandigheden kan eveneens bij $\mathrm{AMvB}$ worden aangevuld. ${ }^{58}$

\section{Vergelijking}

Doordat de consultatieversie voor de minister bevoegdheden creëert waarmee hij ongewenste zeggenschap in specifiek de telecommunicatiesector dient tegen te gaan, bevat de voorgestelde regeling een publiekrechtelijk, sectorspecifiek instrumentarium. Zij voldoet daarmee aan de hiervoor in paragraaf 3.1 en 3.2 genoemde elementen van de aanbeveling uit het WODC-rapport.

In tegenstelling tot de aanbeveling uit het WODC-rapport is in de consultatieversie niet gekozen voor een meldingsplicht voor voorgenomen wijzigingen van zeggenschap in combinatie met een benodigde vvgb. ${ }^{59}$ Uit de memorie van toelichting bij de consultatieversie wordt duidelijk waarom: een dergelijk systeem zou het Nederlandse vestigingsklimaat te veel nadelig beïnvloeden. Naar mijn mening is op dit punt een onjuiste afweging gemaakt. ${ }^{60}$

Doordat een houd- of verkrijgverbod geldt als een besluit in de zin van artikel 1:3 Awb (par. 4.2) is het vatbaar voor bezwaar

56. Art. 14a.2 lid 4 sub b consultatieversie. Wat een 'langdurige onderbreking' en 'een aanzienlijk deel van de diensten en toepassingen die worden geleverd via het internet' inhouden, wordt echter niet duidelijk.

57. Art. $14 a .2$ lid 4 sub f consultatieversie.

58. Art. $14 \mathrm{a} .4 \mathrm{sub}$ h consultatieversie.

59. Aanvankelijk was dat wel de bedoeling (Kamerstukken II 2013/14, 24095, 368).

60. Vgl. hiervoor in par. 3.3. Zie ook Bulten e.a. 2017, p. 255. 
en beroep. Daarmee komt de consultatieversie tegemoet aan de Europeesrechtelijke regel dat een met voldoende waarborgen omklede rechtsgang moet openstaan tegen een maatregel waarmee een inbreuk wordt gemaakt op het ongestoorde genot van eigendom (par. 3.3).

De indruk ontstaat dat in de consultatieversie door middel van gedetailleerde bepalingen is geprobeerd om het toepassingsbereik van de voorgestelde regeling nauwkeurig af te bakenen (par. 4.3). Echter, doordat deconsultatieversie de mogelijkheid biedt om bij $\mathrm{AMvB}$ essentiële onderdelen van het toepassingsbereik (de vitale subprocessen, de gevolgen om relevante invloed aan te nemen en de omstandigheden die tot een gevaar voor de nationale veiligheid kunnen leiden) nader uit te werken, is van een nauwkeurige afbakening geen sprake. Dit stuit mogelijk op Europeesrechtelijke bezwaren. Doordat het toepassingsbereik van de regeling zo niet op voorhand duidelijk kenbaar is, dreigt de regeling een buitenproportionele inbreuk op de vrij-verkeerbepalingen te maken (zie par. 3.4). Een alternatief kan zijn om de vitale processen limitatief in de wet te noemen, maar deze tegelijkertijd ruimer te formuleren. Bijvoorbeeld zoals dat is gedaan in de lijst met vitale infrastructuur. ${ }^{61}$ Mogelijk stuit dit alternatief echter op dezelfde Europeesrechtelijke bezwaren.

Voor de uitleg van het begrip 'overwegende zeggenschap' sluit de consultatieversie deels aan bij bestaande wetgeving. In artikel $14 \mathrm{a} .3 \mathrm{sub}$ a leest men de uitleg die artikel 1:1 Wft an dit begrip geeft. Waarom echter een prioriteitsaandeel per definitie overwegende zeggenschap zou impliceren (art. 14a.3 sub c), valt niet goed in te zien. Er zijn prioriteitsaandelen denkbaar die weliswaar in bijzondere zeggenschap voorzien, maar waarvan moeilijk is vol te houden dat die zeggenschap 'overwegend' is. ${ }^{62}$ Daarnaast is het maar de vraag of situaties van overwegende zeggenschap in de wet limitatief kunnen worden opgeschreven. Zoals gezegd bepleit ik op dit punt aansluiting bij artikel $26 \mathrm{Mw}$ (par. 3.4): overwegende zeggenschap is de mogelijkheid om beslissende invloed uit te oefenen op de ondernemingsactiviteiten van de vennootschap.

Dat de consultatieversie een indicatieve lijst met omstandigheden ter beoordeling van de (on)wenselijkheid van een investeerder bevat, vind ik sterk (vergelijk par. 3.4). De omstandigheden die artikel $14 a .4$ noemt in sub c (het hebben van kort gezegd geen goede staat van dienst), sub $d$ (het onderhouden van nauwe banden met een ongewenst persoon) en sub e (een slechte veiligheidssituatie in het land van herkomst of in de omliggende regio) bieden vermoedelijk alleen wel te weinig rechtszekerheid (par. 4.3).
Een formele mogelijkheid om de minister te vragen of een transactie onder het toepassingsbereik van de regeling valt - welke soortgelijke mogelijkheid in het Duitse recht bestaat $^{63}$-, kent de consultatieversie niet. Ik vind dat een gemiste kans (par. 3.4).

\section{Slot}

Het WODC-rapport raadt de wetgever aan om een publiekrechtelijk, sectorspecifiek instrumentarium te ontwikkelen waarmee ongewenst aandeelhouderschap in vitale vennootschappen kan worden tegengegaan. Ik behandelde de elementen die deze aanbeveling bevat en schetste op basis daarvan hoe de kern van het instrumentarium eruit zou kunnen zien. Vervolgens toetste ik in hoeverre de consultatieversie van het wetsvoorstel Wet voorkoming ongewenste zeggenschap telecommunicatie voldoet aan de aanbeveling uit het WODCrapport. Dat is deels het geval. De belangrijkste pijnpunten in de consultatieversie zijn in mijn ogen het ontbreken van een meldingsplicht in combinatie met een vvgb voorafgaand aan de verkrijging van zeggenschap en een mogelijk onvoldoende kenbaar toepassingsbereik. Tot slot kan voor de invulling van het zeggenschapsbegrip beter worden aangesloten bij artikel $26 \mathrm{Mw}$.

De consultatieversie is nog maar een consultatieversie. Ik ben benieuwd hoe het wetsvoorstel eruit komt te zien.
61. Nationaal Coördinator Terrorismebestrijding en Veiligheid, Nationale veiligheid en crisisbeheersing, NCTV Magazine 2015, afl. 3, p. 6.

62. Bijv. het prioriteitsaandeel dat de houder ervan het recht geeft een voordracht te doen voor de benoeming van een van de vijf bestuurders van de vennootschap.
63. Zie noot 41 . 